\title{
IMPLEMENTASI ALGORITMA SEQUENTIAL SEARCHING UNTUK PENCARIAN NOMOR SURAT PADA SISTEM ARSIP ELEKTRONIK
}

\author{
Anisya Sonita ${ }^{1}$, Mayang Sari ${ }^{2}$ \\ ${ }^{1,2}$ Teknik Informatika, Fakultas Teknik Universitas Muhammadiyah Bengkulu \\ Jl. Bali Po. Box, 118 Kota Bengkulu 38119 \\ (Telp 0736-22765 Fak. 0736-26161) \\ ${ }^{1}$ anisyasonita@umb.ac.id \\ ${ }^{2}$ mayang.sarieasia.com
}

\begin{abstract}
Abstrak: Pengolahan dan pengarsipan nomor surat di Tata Usaha Fakultas Teknik Universitas Muhammadiyah Bengkulu masih menggunakan cara manual yaitu dengan mencatat (tulis tangan) pada buku dan melihat ulang urutan surat sebelumnya untuk memberi nomor pada surat baru. Dengan cara tersebut tentu tidak efisien karena memerlukan buku yang tebal terlebih lagi jika untuk mencatat dalam jangka waktu yang lama dan banyaknya jenis surat yang akan di arsipkan. Tujuan dari penelitian ini yaitu mengimplementasikan algoritma Sequential Searching untuk mempermudah pencarian nomor surat pada sistem arsip elektronik studi kasus tata usaha fakultas teknik Universitas Muhammadiyah Bengkulu. Metode pengembangan sistem yang dipakai dalam penelitian ini adalah metode penelitian RAD atau Rapid Application Development karena, Rapid Application Development (RAD) adalah salah satu metode pengembangan suatu sistem informasi dengan waktu yang relatif singkat. Dari hasil analisa, perancangan, pengujian dan implementasi program yang telah dilakukan terhadap aplikasi Arsip Elektronik ini aplikasi dapat di jalankan dengan baik. Algoritma Sequential Searching dapat di implementasikan pada pencarian arsip berdasarkan nomor surat pada surat masuk dan surat keluar.
\end{abstract}

Kata Kunci : Sequential Searching, Arsip Surat, Algoritma Pencarian, Arsip Elektronik

Abstract: Processing and archiving of the number of letters in the Administration Faculty of Engineering, University of Muhammadiyah Bengkulu still use manual way is to record (handwriting) on the books and see the order in a previous letter to renumber the new letter. In this way the course is inefficient because it requires a thick book especially if to take in a long period of time and the number of mailings that will be archived. The purpose of this study is implement the algorithm Sequential Searching to facilitate the search number of letters in an electronic archive system administration case study engineering faculty in University of Muhammadiyah Bengkulu. System development method used in this study is a research method RAD or Rapid Application Development for Rapid Application Development (RAD) is one method of developing an information system with a relatively short time. From the analysis, design, testing and implementation of programs that have been done on Electronic Archive application is an application can be run properly. Searching Sequential algorithms can be implemented on an archive search by number of letters in the incoming and outgoing mail.

Keywords: Sequential Searching, Archive Letters, Search Algorithm, Electronic Archive

\section{PENDAHULUAN}

Pengolahan dan pengarsipan nomor surat di Tata Usaha Fakultas Teknik Universitas Muhammadiyah Bengkulu masih menggunakan cara manual yaitu dengan mencatat (tulis tangan) pada buku dan melihat ulang urutan surat sebelumnya untuk memberi nomor pada surat baru. Dengan cara tersebut tentu tidak efisien karena memerlukan buku yang tebal terlebih lagi jika untuk mencatat dalam jangka waktu yang lama dan banyaknya jenis surat yang akan di arsipkan. Apalagi permasalahan yang rentan terjadi adalah penyimpanan berkas yang terlalu 
banyak sehingga menjadi kendala saat melakukan pencarian data. Dengan masalah tersebut, penelitian ini akan membuat sistem komputer yang mampu menyimpan arsip tersebut ke dalam memori penyimpanan komputer dan mampu menampilkan nomor surat secara otomatis sehingga pengarsipan dan pemberian nomor surat menjadi lebih efisien. Sistem yang dibuat tentunya memiliki fitur pencarian (Searching) data arsip. Tujuan dari penelitian ini yaitu mengimplementasikan algoritma Sequential Searching untuk mempermudah pencarian nomor surat pada sistem arsip elektronik studi kasus tata usaha fakultas teknik Universitas Muhammadiyah Bengkulu.

Pencarian merupakan proses yang fundamental dalam pengolahan data. Sequential Searching merupakan algoritma pencarian beruntun yang prosesnya membandingkan setiap elemen satu persatu secara beruntun, mulai dari elemen pertama sampai elemen yang di cari di temukan atau seluruh elemen sudah di periksa. Dalam sistem yang akan dibuat dalam peneliian ini, fitur pencarian menggunakan algoritma Sequential Searching untuk mencari nomor surat yang telah di arsipkan. Data arsip yang telah tersimpan di dalam database di kumpulkan pada sebuah Array lalu dari Array tersebut akan di lakukan proses pencarian dengan algoritma Sequential Searching. Jika data yang di cari ada di dalam Array maka data tersebut akan di tampilkan. Jika tidak ada maka akan menampilkan pesan bahwa data tidak ada.

\section{METODE PENELITIAN}

\section{A. Algoritma Sequential Searching}

Sequential Search adalah proses membandingkan setiap elemen array satu persatu secara beruntun dimulai dari elemen pertama hingga elemen yang dicari ditemukan atau hingga elemen terakhir dari array[4]. Metode Sequential Search atau disebut pencarian beruntun dapat digunakan untuk melakukan pencarian data baik pada array yang sudah terurut maupun yang belum terurut. Proses yang terjadi pada metode pencarian ini adalah sebagai berikut [1] : (1) Membaca array data. (2) Menentukan data yang dicari. (3) Mulai dari data pertama sampai dengan data terakhir, data yang dicari dibandingkan dengan masing-masing data di dalam array. Jika data yang dicari tidak ditemukan maka semua data atau elemen array dibandingkan sampai selesai. Jika data yang dicari ditemukan maka perbandingan akan dihentikan

Proses pencarian data dengan metode ini cukup sederhana dan mudah. Proses pencarian data dilakukan dengan mencocokkan data yang dilakukan secara berurut satu demi satu dimulai dari data ke-1 hingga data pada urutan terakhir. Jika data yang dicari mempunyai nilai yang sama dengan data yang ada dalam kelompok data, berarti data telah ditemukan. Jika data yang dicari tidak ada yang cocok dengan data dalam sekelompok data, data tersebut tidak ada dalam sekelompok data. Selanjutnya kita tinggal menampilkan hasil yang diperoleh tersebut.

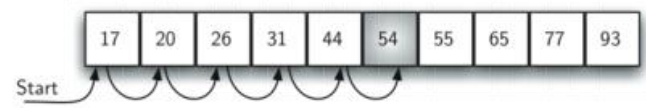

Gambar 1. Sequential Searching

Adapun Proses Algoritma Sequential Searching adalah sebagai berikut:

a. Pertama data melakukan perbandingan satu per satu secara berurutan dalam kumpulan data dengan data yang di cari sampai data tersebut ditemukan atau tidak ditemukan. 
b. Pada dasarnya, pencarian ini hanya melakukan pengulangan data dari 1 sampai dengan jumlah data (n).

c. Setiap pengulangan, dibandingkan data ke-i dengan data yang sedang dicari.

d. Apabila data sama dengan yang dicari, berarti data telah berhasil di temukan. Sebaliknya apabila sampai akhir melakukan pengulangan tidak ada data yang sama dengan yang dicari, berarti data tidak ada yang ditemukan.

Urutan Algoritma Sequential Searching:

1. $\mathrm{i}<-0$

2. Ketemu $<$ - false

3. Selama ( tidak ketemu ) dan $(\mathrm{i}<\mathrm{N})$ kerjakan baris 4

4. Jika ( Data[i] = key ) maka ketemu <- true Jika tidak $\mathrm{i}<-\mathrm{i}+1$

5. Jika ( Ketemu ) maka i adalah indeks dari data yang dicari

B. Arsip
Arsip adalah "rekaman kegiatan atau peristiwa dalam berbagai bentuk dan media sesuai dengan perkembangan teknologi informasi dan komunikasi yang dibuat dan diterima oleh lembaga Negara, pemerintahan daerah, lembaga pendidikan, perusahaan, organisasi politik, organisasi kemasyarakatan, dan perseorangan dalam pelaksanaan kehidupan bermasyarakat, berbangsa dan bernegara" [2].

\section{Metode Pengembangan Sistem}

Metode pengembangan sistem yang dipakai dalam penelitian ini adalah metode penelitian RAD atau Rapid Application Development karena, Rapid Application Development (RAD) adalah salah satu metode pengembangan suatu sistem informasi dengan waktu yang relatif singkat[3]. Siklus RAD dapat di tunjukan pada gambar berikut:

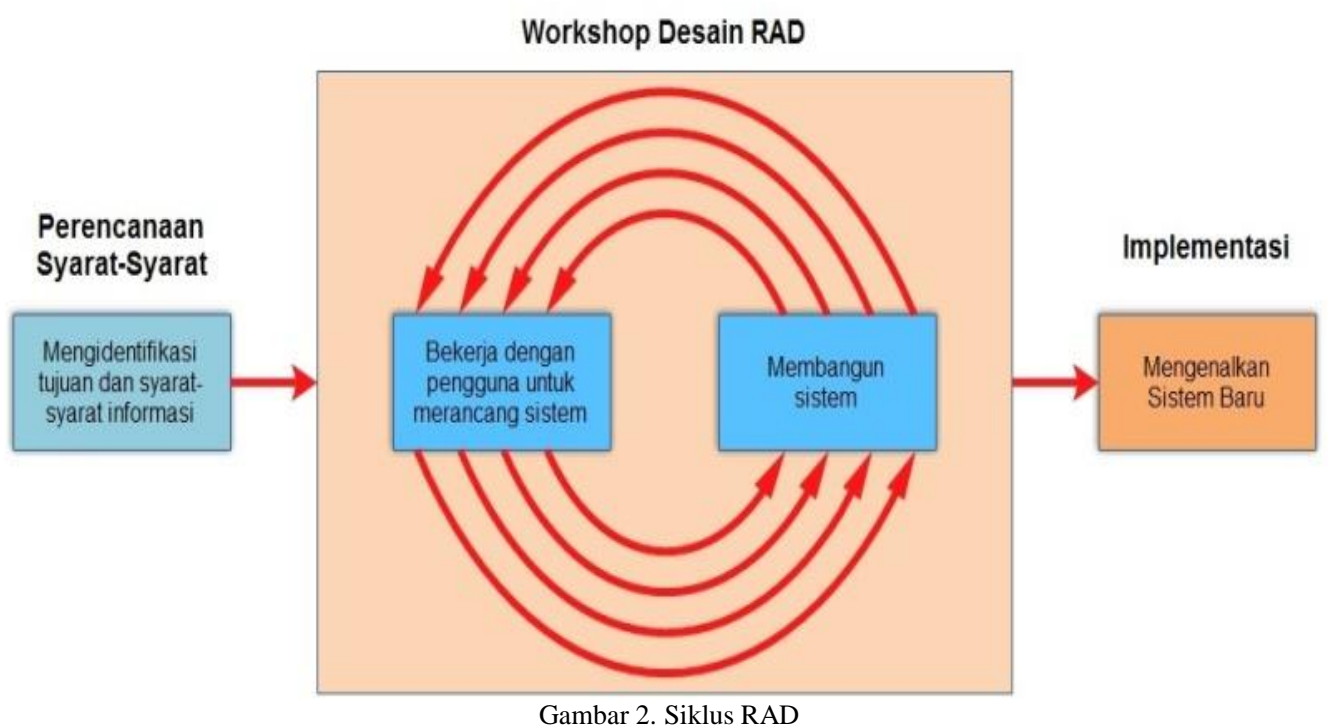

\section{Workshop Desain RAD}

Pada fase ini yang dapat dilakukan adalah membangun dan menunjukkan representasi visual desain dan pola kerja kepada pengguna. Selama workshop desain RAD, pengguna merespon prototipe yang ada dan penganalisis memperbaiki modul-modul yang dirancang berdasarkan respon pengguna. Adapun flowchart dari kerja sistem ini adalah sebegai berikut: 


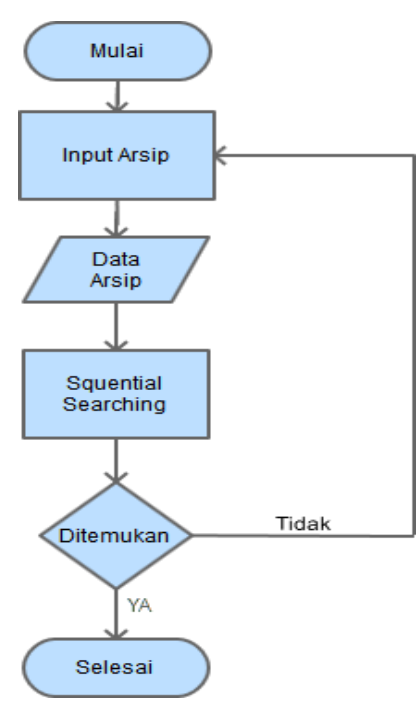

Gambar 3. Flowchart kerja system

2. Implementasi

Tahap awal, user menginputkan data nomor dan arsip pada aplikasi arsip elektronik lalu data yang di inputkan tersebut tersimpan ke dalam database. Dari database, saat pengguna ingin mencari data tertentu pada database dengan fitur pencarian maka, Algoritma Sequential Searching akan bekerja mencari data sesuai dengan keyword atau kata kunci pencarian yang di inputkan oleh user.

\section{HASIL DAN PEMBAHASAN}

\section{A. Hasil Penelitian}

Hasil perancangan aplikasi untuk pencarian nomor surat pada sistem arsip elektronik dijelaskan sebagai berikut:

1. Menu Login

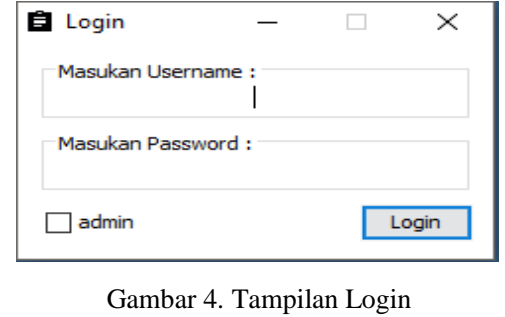

Pada saat aplikasi pertama kali di jalankan, pengguna harus melakukan login. Hanya pengguna yang memiliki akun yang dapat menggunakan aplikasi ini. Pada aplikasi ini, terdapat dua macam level pengguna yaitu pengguna biasa (user) dan admin. Pengguna dengan level user hanya dapat mengakses menu surat masuk dan surat keluar sedangkan pengguna dengan level admin dapat mengakses keseluruhan menu dan fitur aplikasi. Admin juga dapat menambahkan akun pengguna baru. Pada aplikasi arsip elektronik ini, sistem keamanan kata sandi menggunakan MD5 sebagai keamanan informasi pengguna.

\section{Menu Utama}

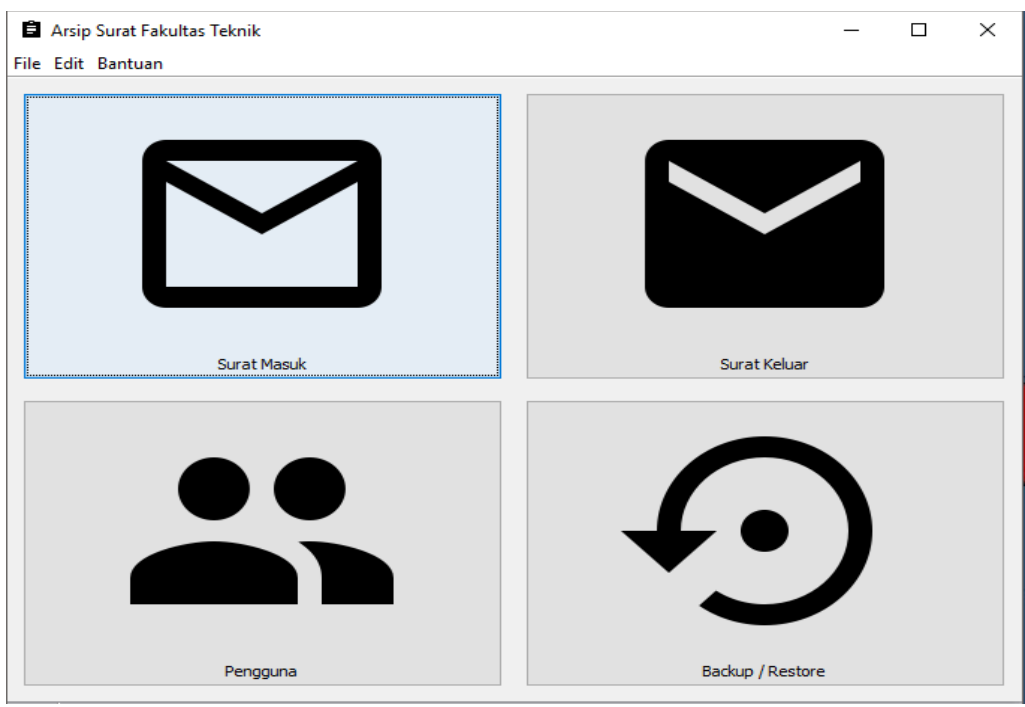

Gambar 5. Tampilan Menu Utama 
Pada menu utama juga terdapat menu bar dan status bar. Pada status bar terdapat nama pengguna yang sedang menggunakan aplikasi atau nama pengguna yang sedang login aplikasi.

\section{Menu Surat Masuk}

Pada menu surat masuk, pengguna dapat menambahkan arsip surat masuk dengan mengklik tombol tambah lalu menginputkan data arsip surat tersebut langsung pada tabel surat masuk. Untuk menghapus, pengguna harus memilih atau menandai baris data yang akan di hapus. Pada menu surat masuk ini terdapat fitur pencarian berdasarkan nomor urut dan filter data surat masuk berdasarkan karakter yang di ketikan pada kolom pencarian. Pencarian arsip pada menu surat masuk ini menggunakan metode pencarian Sequential Search untuk pencarian berdasarkan nomor surat. Sedangkan pada filter pencarian menggunakan pencarian standar berdasarkan query SQL.

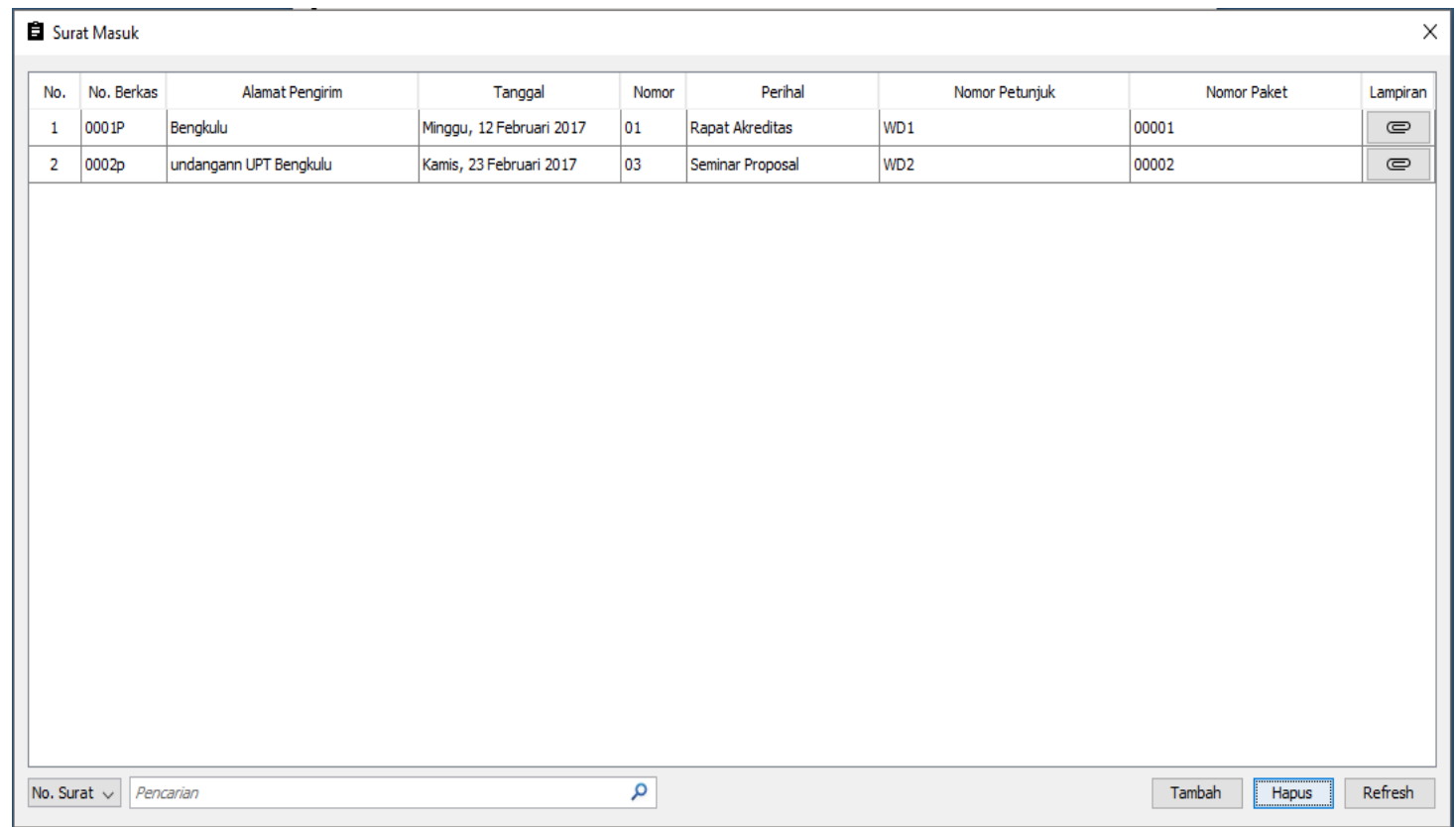

Gambar 6. Tampilan Menu Surat Masuk

\begin{tabular}{|c|c|c|c|c|c|c|c|}
\hline No. & No. Berkas & Alamat Penerima & Tanggal & Perihal & Nomor Petunjuk & Nomor & Lampiran \\
\hline 1 & 001 & WR-II-UMB & Rabu, 8 Februari 2017 & Ajuan Dana UAS & Dekan & 134 & e \\
\hline 2 & 002 & Satiadi purnam & Kamis, 9 Februari 2017 & legalisir ijazah & dekan & 135 & ee \\
\hline
\end{tabular}

No. Surat $\vee$ Pencarian

Gambar 7. Tampilan Menu Surat Keluar 


\section{Menu Surat Keluar}

Pada menu surat keluar ini fitur pengolahan data sama seperti surat masuk. Pada menu surat keluar ini juga terdapat fitur pencarian berdasarkan nomor urut dan filter data surat keluar berdasarkan karakter yang di ketikan pada kolom pencarian. Pencarian arsip pada menu surat keluar ini menggunakan metode pencarian Sequential Search.

Pada Menu Surat Masuk dan Menu Surat Keluar, pengguna juga dapat menggunakan fasilitas pengguna dapat melampirkan berkas berupa dokumen dan foto hasil Scan menggunakan Scaner.

\begin{tabular}{|l|l|}
\hline G Lampiran & \\
\hline & OK \\
\hline & Oaftar Lampiran \\
& Tambah \\
\hline & Hapus \\
\hline & Lihat \\
\hline
\end{tabular}

Gambar 8. Tampilan Menu Lampiran

\section{Menu Pengguna}

Menu pengguna hanya dapat di akses oleh pengguna yang memiliki level admin. Pada menu ini, admin dapat melihat data-data akun pengguna yang memiliki hak untuk login dan menggunakan aplikasi. Admin juga dapat menghapus dan mendaftarkan akun pengguna baru. Untuk menghapus pengguna, admin harus memilih data dari pengguna yang akan di hapus lalu menekan tombol hapus. Untuk menambahkan akun pengguna baru, admin dapat menambahkannya pada tab Tambah Pengguna lalu masukan informasi pengguna seperti level pengguna, nama lengkap, username dan password akun. Tampilan opsi tambah akun pengguna dapat di lihat pada gambar di bawah ini.

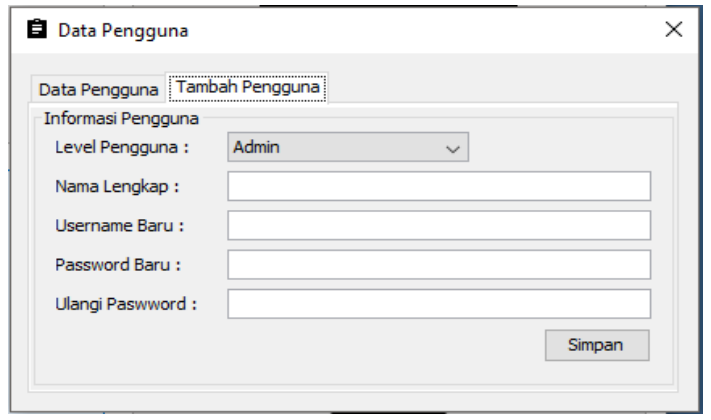

Gambar 9. Tampilan Tambah Pengguna

\section{Menu Backup/Restore}

Pada menu ini, pengguna dapat membuat backup atau cadangan data arsip surat dan menyimpannya pada media penyimpanan lain seperti flashdisk, cd/dvd, hardisk dan penyimpanan elektronik lainnya.

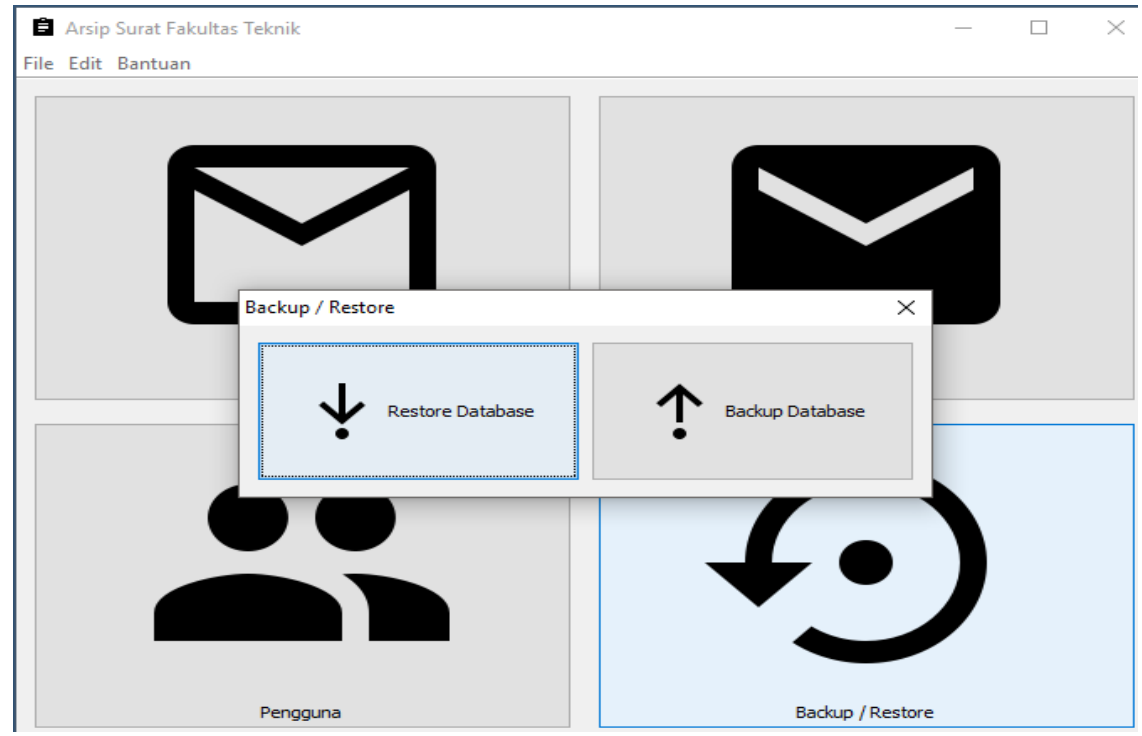

Gambar 10. Tampilan menu Backup \& Restore 
Jurnal Pseudocode, Volume V Nomor 1, Februari 2018, ISSN 2355-5920 www.ejournal.unib.ac.id/index.php/pseudocode

Hal ini tentu sangat bermanfaat jika suatu saat terjadi kerusakan data atau bahkan kerusakan pada komputer. Pada menu ini juga pengguna dapat memulihkan kembali data hasil backup tersebut dengan tombol Restore, sebelumnya file hasil backup telah di pilih dengan tombol Browse.

\section{Proses Backup}

Pada opsi ini pengguna memilih lokasi penyimpanan file backup, lokasi penyimpanan file backup dapat di simpan di hardisk, flashdisk atau pun media penyimpanan lainnya.

\section{Restore}

Pada opsi ini pengguna mencari di mana file backup yang sebelumnya telah di buat lalu pengguna memilih file tersebut untuk memulai proses pemulihan atau restore data.

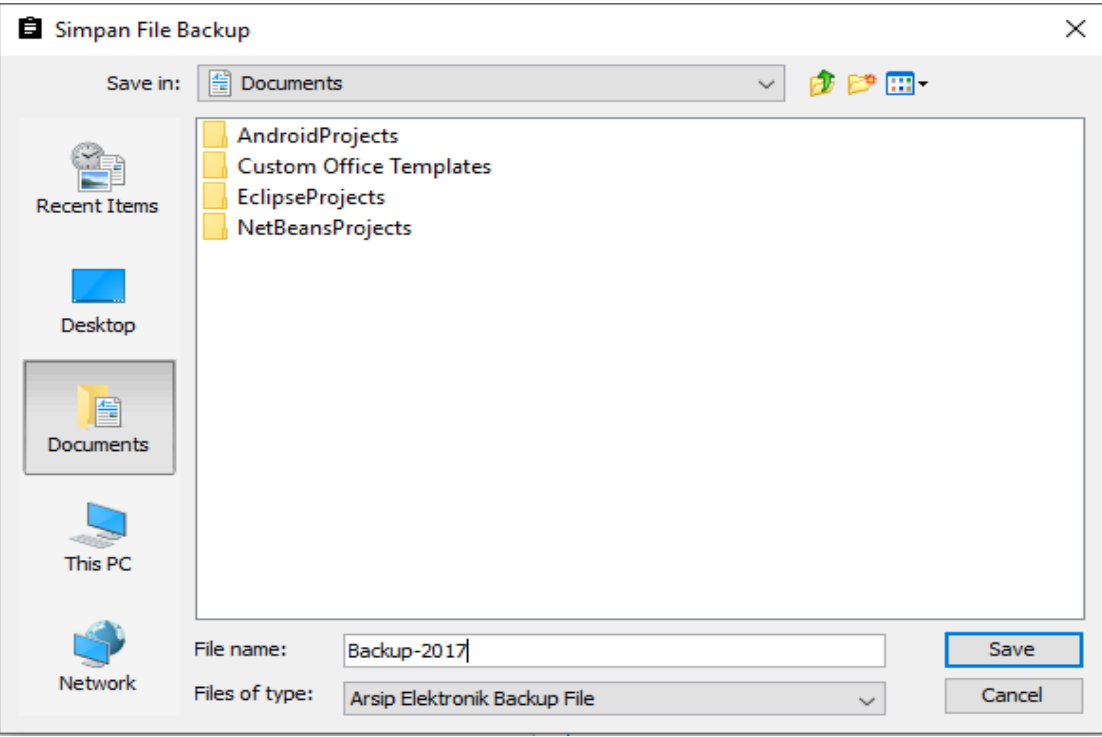

Gambar 11. Proses Penyimpanan File Backup

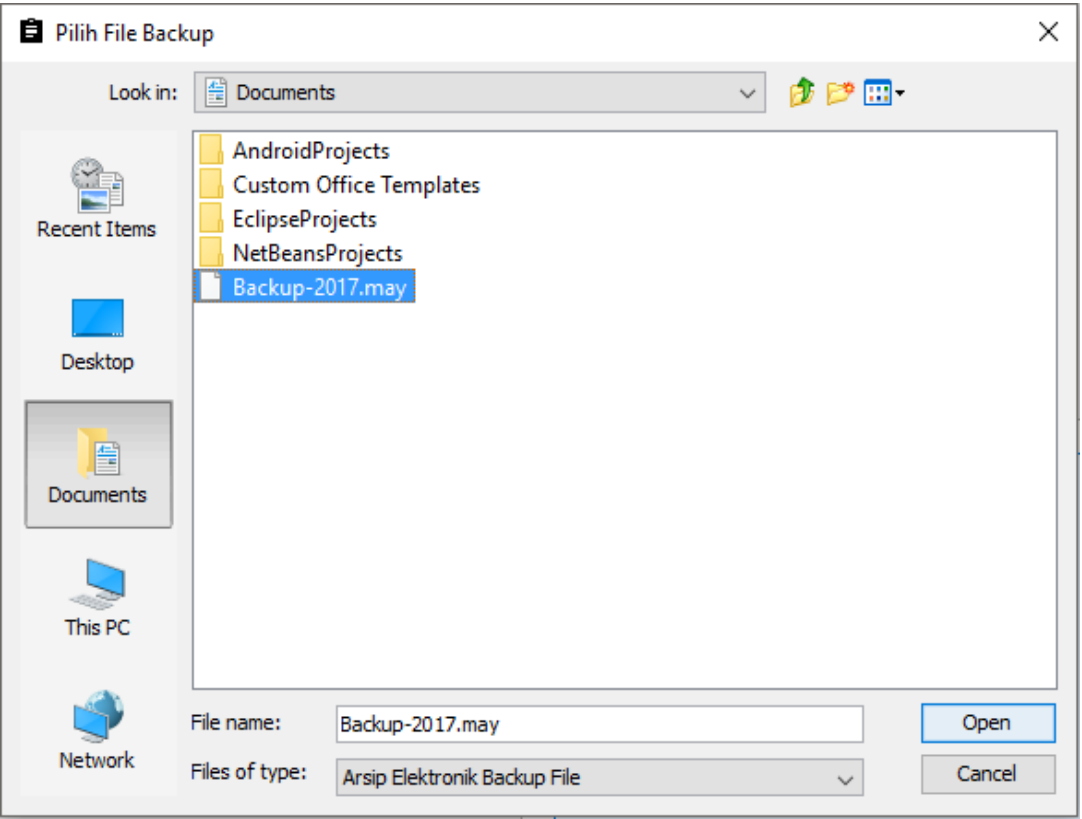

Gambar 12. Proses Restore 


\section{B. Pembahasan}

1. Implementasi Algoritma Sequential Search

Sequential Searching adalah teknik pencarian data di mana data dicari secara urut dari depan ke belakang atau dari awal sampai akhir. Pada menu surat masuk dan menu surat keluar terdapat kolom pencarian seperti gambar di bawah ini.

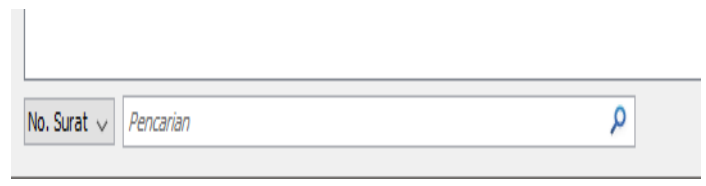

Gambar 13. Kolom Pencarian

Pada fitur pencarian inilah Sequential Searching bekerja ketika pengguna menginputkan kata kunci pencarian pada kolom pencarian lalu sistem akan bekerja dan mencari dan menampilkan data yang pengguna cari. Jika data yang di cari ada pada database, maka sistem akan menampilkan data seperti gambar 15 .
Namun jika data yang di cari tidak ada makan sistem akan menampilkan pesan seperti gambar berikut.

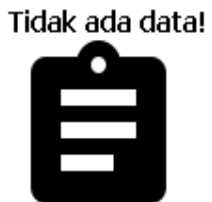

Gambar 14. Data tidak ditemukan

Sistem pencarian pada arsip elektronik ini algoritma Sequential Searching terjadi secara real-time dengan kata lain sistem melakukan pencarian secara langsung ketika pengguna selesai mengetik kata kunci pada kolom pencarian, teknik ini memanfaatkan fitur Java Event yaitu KeyEvent pada class java.awt.event.KeyEvent.Dengan teknik ini pencarian akan menjadi lebih simpel dan cepat di lakukan. Berikut cuplikan kode algoritma Sequential Searching yang di terapkan pada aplikasi pada Gambar 16.

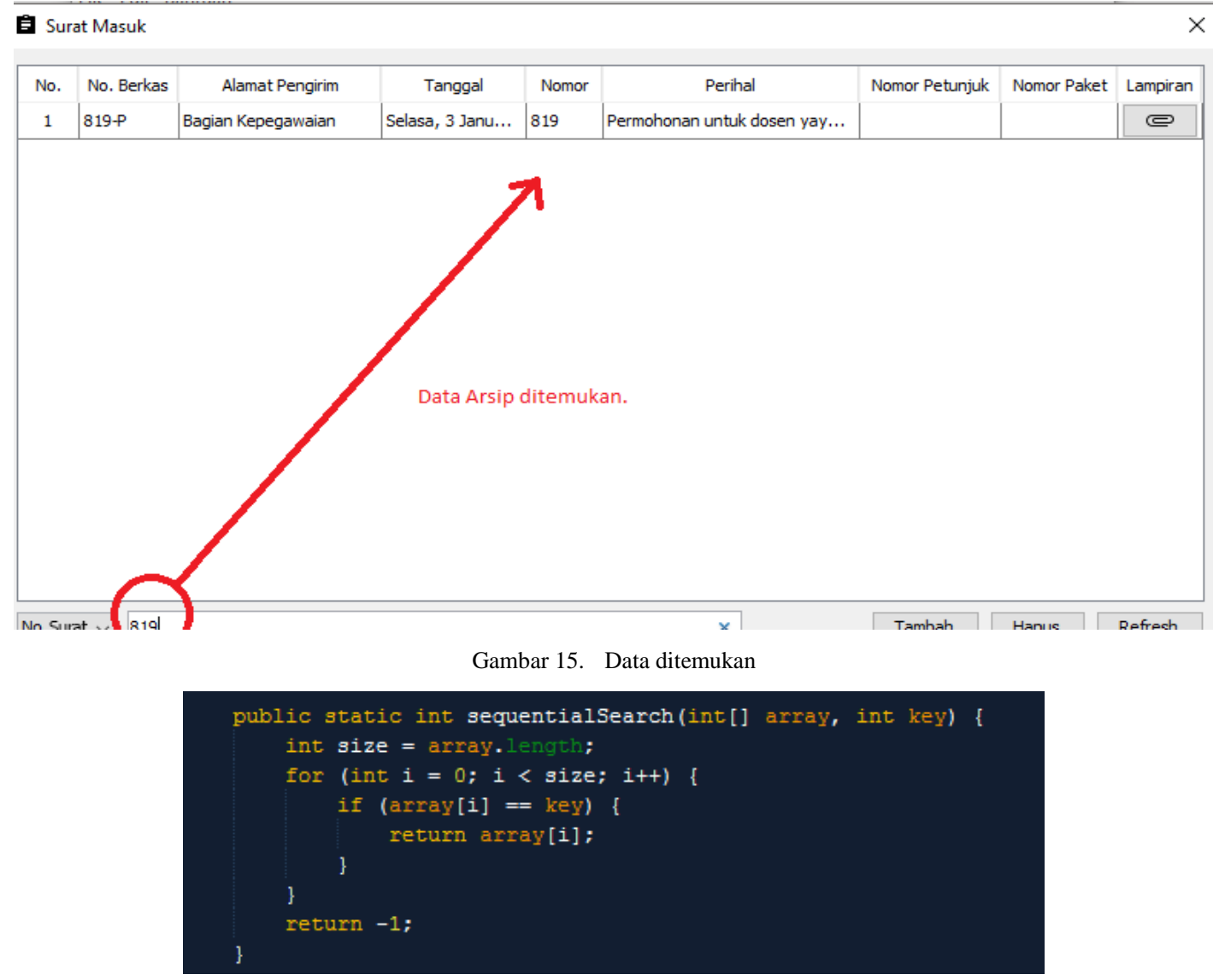

Gambar 16. Kode Algoritma Sequential Searching 
Pada kode program di atas dapat dilihat, Method sequential Search memiliki dua parameter yaitu array dan key di mana array adalah kumpulan data dengan tipe integer dan key merupakan kata kunci atau data yang akan di cari pada kumpulan data tersebut. Method merupakan sekumpulan instruksi atau perintah program yang di beri nama tertentu.

\section{Proses kerja algoritma Sequential Search}

Semua data yang tersimpan pada database di panggil lalu di simpan pada array. Pada array data yang tersimpan hanya nomor surat saja karena pencarian akan di lakukan berdasarkan nomor surat saja sesuai dengan perencanaan pada bab sebelumnya. Berikut proses kerja algoritma Sequential Searching:

1. Menentukan jumlah data yang tersimpan pada array.

$$
\text { intsize }=\text { array.length; }
$$

2. Melakukan perulangan FOR sebanyak jumlah data dan melakukan pencarian secara beruntun atau sekuensial terhadap data-data yang tersimpan data array.

$$
\text { for (int } \mathrm{i}=0 \text {; } \mathrm{i}<\text { size; } \mathrm{i}++ \text { ) }
$$

3. Menentukan kecocokan data yang tersimpan di array dengan kata kunci yang di cari (key) menggunakan perintah IF

$$
\text { if }(\operatorname{array}[\mathrm{i}]==\mathrm{key})
$$

4. Jika data yang di cari di temukan atau cocok maka nilai akan di kembalikan dengan nilai pencarian dan pencarian di hentikan.

$$
\text { return array[i]; }
$$

5. Jika data tidak di temukan, maka nilai akan di kembalikan dengan ke -1 sebagai indikasi data tidak ada.

return -1 ;

\section{KESIMPULAN}

Dari hasil analisa, perancangan, pengujian dan implementasi program yang telah dilakukan terhadap aplikasi Arsip Elektronik, dapat disimpulkan sebagai berikut:

1. Aplikasi Arsip Elektronik dapat di jalankan dengan baik. Dari hasil pengujian dari berbagai aspek aplikasi telah sesuai dengan perencanaan dan tujuan penelitian.

2. Algoritma Sequential Searching dapat di terapkan pada pencarian arsip berdasarkan nomor arsip dan berjalan dengan baik sesuai perencanaan.

3. Hampir semua permasalahan pada sistem arsip manual dapat teratasi dengan adanya sistem arsip elektronik ini. Dari segi penyimpanan, pengolahan dan proses menjadi lebih efisien.

\section{REFERENSI}

[1]. Atmaja, Eduardus Hardika Sandy, and Eko Hari Parnadi. "Aplikasi Penjadwalan Perkuliahan Menggunakan Algoritma Sequential Search Dan Forward Checking." SEMNASTEKNOMEDIA ONLINE 2.1 (2014): 2-04. 31 - 35

[2]. Muhsin, dan Aditya Yudha Primantoro. 2015. "Sistem Pengelolaan Arsip Di Kantor Perum Perhutani Divisi Regional Jawa Tengah." Economic Education Analysis Journal 362-375.

[3]. Noertjahyana, A, "Studi Analisis Rapid Aplication Development Sebagai Salah Satu Alternatif Metode Pengembangan Perangkat Lunak", JURNAL INFORMATIKA Vol. 3, No. 2, Nopember 2002: 74 79

[4]. Sitorus, Lamhot, "Algoritma dan Pemrograman", Andi, Yogyakarta, 2015 